\title{
Nonlinear Effects of Financial Sector Development on Iran Economic Growth: With an Emphasis on the Role of Interest Rate
}

\author{
Nooshin Khani Gharie Gapy \\ $\mathrm{PhD}$ in Economics, Lecturer of Imam Reza International University, Mashhad, Iran \\ E-mail: Nooshin.khani@gmail.com
}

Seyed Mohammad Hadi Sobhanian

$\mathrm{PhD}$ in Economics, Faculty member of Kharazmi University,Tehran, Iran

E-mail: hadi.sobhanian@gmail.com

Susanne Soretz

Faculty member of Ernst-Moritz-Arndt University Greifswald, Germany

E-mail: soretz@uni-greifswald.de

Bahram Sahabi

Faculty member of Tarbiat Modares University (T.M.U), Tehran, Iran

E-mail: sahabi_b@modares.ac.ir

Received: May 19, 2015 Accepted: June 2, 2015

doi:10.5296/ber.v5i2.8016

URL: http://dx.doi.org/10.5296/ber.v5i2.8016

\begin{abstract}
In this paper, a threshold error correction approach is used to analyze whether in various interest rate regimes, the effectivity of financial development indicators on economic growth rate is different or not. Over the period 1973 - 2007, we show that in high interest rate regime, stock index's growth rate and growth rate of banking facilities indicator (as financial
\end{abstract}


development indicators), have positive effect on Iran economic growth. Nevertheless, in low interest rate regime, financial development reduces Iran economic growth. Basically this negative impact can be attributed to negative real interest rate due to high inflation. Furthermore we question whether financial index growth will equally affect economic growth before and after crossing a threshold level. Our results suggest that when threshold variable is considered as banking facilities index, there is no linear relationship between the mentioned index growth and economic growth. However, when the stock index is considered as a threshold variable, passing the threshold level will promote economic growth.

Keywords: Economic growth, Financial index, Interest rate, Threshold error correction model

\section{Introduction}

Several theories have been proposed by economists regarding the relationship between financial development and economic growth. After Bagehot (1813), for the first time, Schumpeter (1911) pointed to the importance of the financial sector in supporting economic growth. In recent years, numerous studies have been done on the role of financial sector on economy's development and prosperity. Also, several papers have been published that use panel data and time series data methods to explain the different growth rates across different countries. One of the key findings in the literature is concerning the empirical and strong relationship between financial sector development and economic growth. Levine (1997) and Wachtel (2001) are among those who conducted significant studies in this regard. Most theoretical and empirical evidence suggests a positive impact of financial sector development on economic growth. In short, increased use of financial intermediaries and intermediation will encourage savings and investment and improve the allocation of savings to investment projects; these encouragements in turn lead to the higher levels of capital formation and productivity in capital allocation.

Recent investigations have focused on economic conditions that enforce or weaken the relationship between financial development and economic growth. In this regard, using financial data related to more than 65 developing countries Narayan and Kumar (2013) analyze the relationship for various regional panels. Their main findings are that while for the full panel of 65 countries there is evidence for financial sector-led growth; bank credit has a negative effect on economic growth. At the regional level, for the Middle Eastern countries neither the financial sector nor the banking sector enhances growth. Except for Asia, the role of financial sector development on economic growth is relatively weak. Finally, except for the Middle Eastern countries, clear evidence is found in favor of bank credit having a statistically significant and negative effect on economic growth. Sassi and Goaied (2013) test whether the impact of financial development on growth is corroborated by better $\mathrm{ICT}^{1}$ infrastructure. The authors use data from some MENA $^{2}$ countries and a dynamic panel

$$
\text { Information Communication Technology (ICT) - }
$$

Middle East and North Africa (MENA) the term refers to the region from Morocco to Iran - 
model with system GMM estimators. They find that the interaction between ICT penetration and financial development is positive and significant in the growth regression. Ahmed (2013) investigates the role of financial liberalization in raising financial deepening and economic growth in Sub-Saharan African countries (SSA). Data from 21 countries in Sub-Saharan Africa over the period of 1981-2009 is used in a dynamic panel data approach with GMM estimator. The research finds that financial liberalization does impact positively on financial deepening and resource mobilization in SSA region, after controlling for key macroeconomic factors such as institutional quality, fiscal imbalances and inflation. Huang and Chang (2010) in their study investigate whether real interest rates are associated with a stronger or weaker finance-growth relationship in the Japanese economy. This study confirms the substantial effects of real interest rates on finance-growth relationships in Japan. In the regime with higher (lower) real interest rates, the banking system has significantly positive (adverse) effects on output growth. Rioja and Valev (2004) found that the relationship between the financial sector and economic growth varies according to the different levels of financial development. In countries with very low levels of financial development, development in the financial markets has no effect on economic growth. In countries with average levels of financial development, in contrast financial sector has a great and positive effect on growth. Finally, in countries where financial development is high, the effect of financial development on economic growth is positive but smaller.

Until the early 1970s, the prevailing opinion was that savings are only stimulated through income and an interest increase is less important to encourage investment expenditure. Likewise, the impact of interest rates on savings was not clear. Accordingly, Malho (1986) argues that saving and investment behavior is dynamically determined by a set of forces. One of the crucial factors is the interest rate. When the real interest rate becomes negative due to high inflation rate, literally a financial repression takes place in the economy (controlled banking system). Consequently credit rationing control, investment and ultimately the production level will be the main victims of this policy (Van Wijnbergn, 1983). There have been extensive studies and discussions on the issues associated with the impact of financial liberation policies on economic growth as well as on other macroeconomic variables (among them, McKinnon and Shaw (1973), Malho (1986) and Fry (1982) can be noted. For example, McKinnon and Shaw (1973) focus on developing countries encountering financial repression and argue that investors' access to foreign financial markets is very limited as a consequence of financial repression in developing countries. This may lead to the accumulation of monetary funds (bank deposits) and thus investment in physical properties. In such a situation, an increase in deposit rates possibly will increase savings and investment.

Since the impact of inflation rate in Iran's economy has been constantly two-digit in the past three decades, the real interest rate got negative in several years and the country went through financial repression. Therefore, considering the impact of real interest rate on the relationship between financial development and economic growth in Iran is of utmost importance. Thus far, many authors have made use of a wide variety of econometric methods in order to examine the relationship between financial development and economic growth in Iran; however, no study has been concerned about the role of real interest rate and its impact on the 
relationship between financial development and economic growth. Therefore, the present study is an attempt to investigate the hidden aspects of this issue in Iran's economy. In this paper we focus on the nonlinear relationship between financial variables and Iran's economic growth. We use a different method of threshold error correction in order to evaluate this issue. This method enables us to determine direction and amount of the influence of the financial sector on Iran's economic growth. Moreover, we specify a threshold growth rate of different financial development indexes and of the real interest rate. We examine the role of interest rate as an effective economic variable on the relationship between financial sector growth and economic development. We show that the effect of financial development indicators on economic growth rate depends on the level of the interest rate. In a high interest rate regime financial index growth has a positive impact on economic growth. Nevertheless, this effect vanishes in low interest regime. Similarly, the growth enhancing effect of financial development indexes predominantly occurs if the positive development of the financial sector is strong enough.

The outline of the paper is as follows: The next section gives a short overview of Iran economic development, Section 3 illustrates the relationship between financial development and economic growth, Section 4 explains the study's theoretical framework, section 5 outlines the econometric models and data, section 6 describes the empirical result and the final section obtains conclusions.

\section{A Selection of Iran's Economic Experience with an Emphasis on the Monetary Policies}

Iran is the second largest oil exporter among the OPEC countries. Eighty percent of Iranian exports are based on the export of oil and gas, other products derived from them, and on average, it includes over 50 percent of government revenue. The economy of Iran is one of the few economies in the world that were not directly affected during the 2007-2009 financial crises. In 1970s, in Iran, economic growth was negative and inflation was high which was mostly derived from the uptrend of liquidity and aggregate demand. The inflationary pressure and subsequently the reduction of people's propensity to save due to fixed interest rates caused to implement restrictive monetary policies, such as increasing the re-discount rate, the interest rate, and the legal reserve requirements rate as well as determining the maximum credit to the private sector in Iran. In recent years, the economic space was dominated by fiscal policy and which took away the impact of monetary policy tools. At this time, Iran's monetary policy tools included open market operations, setting official discount rate, setting the legal reserve requirements and credit ceilings.

After the Islamic Revolution and during 1979 to 1989, the interest-free banking act eliminated the interest rate and replaced the banking profit rate. In these years, monetary policies were mainly setting the legal reserve requirements and credit ceilings. By looking at the average of variables such as the economic growth rate $(-4.5 \%)$, liquidity growth rate $(20 \%)$, and inflation (19\%), it can be concluded that during these years monetary policy did not have an acceptable performance. Generally, since before the end years of revolution until the early years after the revolution, monetary policy has continued due to high rates of 
liquidity growth. Financing the war was the first priority during the war (i.e. 1983 to 1989), and lead to an increase in government expenditure, consequently fiscal policy dominated more and more in the economy. In 1982 and 1983, due to rising oil revenues and therefore, increasing opportunities for investment, the economic growth rate became positive. After these two years, the oil revenues again declined and until the end of imposing war, the economic growth was negative. Simultaneously the liquidity to provide the government budget deficit was increased. In 1980s and largely in 1990s, the main tool for monetary policy was in terms of conventional tools, legal reserve requirements, and changes in least interest rate and the open market operations did not contribute.

However, with the entry into 1990s and beginning the first development plan, the oil revenues increased and the possibility of outside funding and selling currencies was added to the monetary policy tools. The first development plan was almost successfully completed but by the occurrence of crisis 1994 and declining the oil revenues, the economic fluctuations increased and growth rate was reduced. During this period, inflation rose increasingly and in 1995 , it was $49.5 \%$ (i.e. the highest figure in Iranian economic history and by adopting restrictive fiscal and monetary policies, the government tried to control the inflation). In 1997 and 1998 due to the crisis in Southeast Asian countries, oil revenues declined and the budget deficit was positive again. In the third plan, one of the main policies was establishing the foreign exchange reserves fund that kept the country's economy from the possible fluctuations resulting from increasing oil revenues. It led to establish fiscal discipline and eliminate the fiscal policy domination. At the same time, the bonds were ratified as an instrument of monetary policy. Since 2000 , this tool has been used as a tool for open market operations. Some actions were taken in this plan including development of e-banking, reform of the payment system, increasing the private banks' share, privatization of state banks, exchange rate reform and excluding the multiple rates, review the banking interest rate, reduction in legal reserve requirements and they continued in the fourth plan. The success of the third plan is demonstrated in terms of $7.9 \%$ economic growth, $14.1 \%$ inflation, and $12.6 \%$ unemployment. In the early years of the fourth plan, the act of how to determine the interest rate (the interest rate rationalization) was approved. Because of high inflation more difficult situations appeared which resulted in lower economic growth.

Chart (1) summarizes the monetary policies in terms of savings and lending real rates (interest rate). According to this figure, due to the negative loans interest rate, in fact, the depositors are charged and the deposit with lower rate is available to the investors. This trend will also continue in the subsequent years. In the third plan, which controlled inflation, some real rates became positive. However, continuing the obligatory and financially dominated policies associated with rising inflation resulted in a negative real interest rate. 


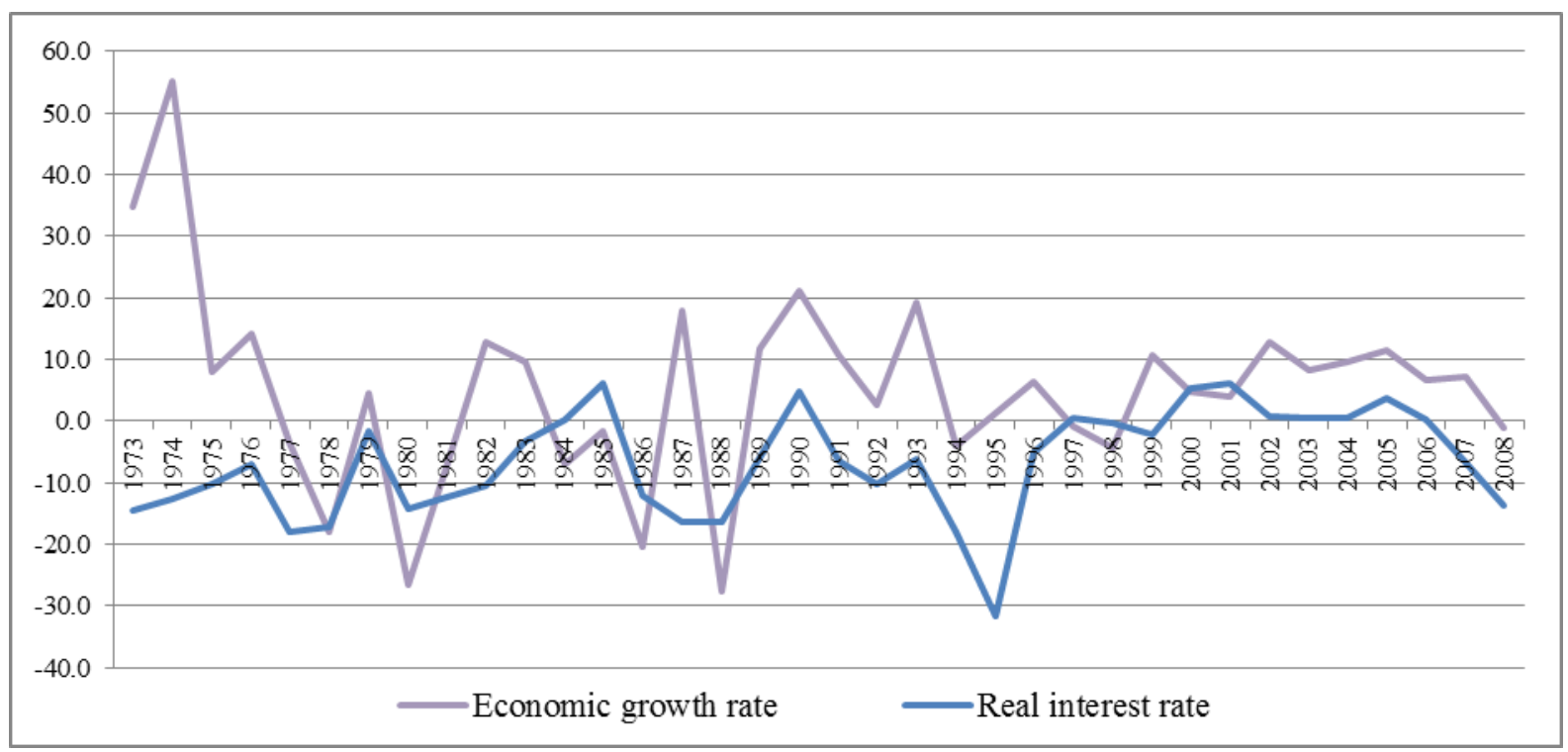

Figure 1. Annual real interest rate and Economic growth rate of Iran (percentage)

\section{The Relationship between Financial Sector Development and Economic Growth}

In this section we use the well-known linear endogenous growth model (AK-model) to give a short insight into the relationship between financial sector development and economic growth, as proposed by Pagano (1993). The total amount of production, $Y_{t}$, is proportional to aggregate capital, $K_{t}$ :

$$
Y_{t}=A K_{t}
$$

According to Romer (1986) this equation can be imagined as the aggregate of $N$ homogenous firms, each of them having an individual production function shaped $y_{t}=B k_{t}^{\alpha}$. Parameter $B$ is exogenous to the individual firm. Nevertheless, it is determined based on the average amount of capital, i.e. $B=A k_{t}^{1-\alpha}$. Alternatively, we can assume that $K$ is a combination of physical and human capital, following Lucas (1988), or a combination of physical capital and a productive public input, as in Barro (1990).

For simplicity, we assume that population is stationary and the economy produces only one homogenous good that can be consumed or invested. If invested it will be subject to the depreciation rate $\delta$. As a result, gross investment will be equal to:

$$
I_{t}=K_{t+1}-(1-\delta) K_{t}
$$

In a closed economy without government activity, net saving $\left(S_{t}\right)$ should equal net investment 
$\left(I_{t}\right)$, in order to ensure capital market clearing. Now, regarding the costs of financial intermediation, we assume a loss of $(1-\varphi)$ of the savings, hence capital market equilibrium results in

$$
\varphi S_{t}=I_{t}
$$

In this case, $\varphi$ is an indicator of the efficiency of financial intermediation, which converts the available saving resources to investment. The difference between savings and investment is another part of the savings, which is given to banks, brokers and dealers as commission rate.

From equation (1), the growth rate in the period $(t+1)$ is given as follows:

$$
g_{t+1}=\frac{Y_{t+1}-Y_{t}}{Y_{t}}=\frac{K_{t+1}-K_{t}}{K_{t}}
$$

By using equation (2) and deleting the time index, the growth rate in the steady state follows immediately:

$$
g=A \frac{I}{Y}-\delta=A \varphi s-\delta
$$

where $s=\frac{s}{Y}$ denotes the savings rate.

Equation (5) shows that financial sector development may influence economic growth directly through the efficiency of financial intermediation ( $\varphi$ increases). Moreover, financial sector development has an indirect positive impact on growth if the rate of savings $(s)$ is increased or if the total factor productivity $(A)$ is increased.

Reviewing the historical growth process of England, Hicks (1969) suggests the development of financial markets to be the main reason for the formation of the industrial revolution. This reflects the importance of financial sector development for economic growth. As previously mentioned, this theory focuses on the supply side. The most important studies on this theoretical framework are McKinnon (1973) and Shaw (1973). They show that financial development can be identified as cause of the divergence in the growth rates of different countries. According to McKinnon and Shaw, financial development with increasing savings as well as investment will lead to faster economic growth. Many empirical studies have been done in this area. Among the more recent studies we emphasize Levine and Zervos (1998) who show that banking development fosters economic growth. But long ago other studies like Robinson (1958) already state that economic growth creates demand for financial services. In fact, financial development also is a response of financial markets to the increasing demand for financial intermediation, see e.g. Ireland (1944). 
On the other hand, Lucas (1988) denies the importance of financial institutions for economic growth. In his opinion the role of financial markets is overestimated, they play only a small role in economic growth. Using endogenous growth models and the possibility of assessing the causal relationship between variables, a new perspective emerged, which combined the analysis of supply and demand side. Following this perspective, financial development and economic growth are interdependent. This view is supported by many empirical studies, including Demetrius and Hussein (1996) who investigate data from 16 countries and as a result confirmed the bilateral causal relationship. Empirical studies which focus on financial development of oil exporting countries indicate a general weakness of financial markets in these countries. Naceur and Ghazooni (2007) analyze 11 countries which are members of MENA region. In these countries, financial development can be shown to have little impact on economic growth. And the isolated effect of banks even indicates a negative impact of financial development on economic growth. These findings encouraged us to search for a nonlinear relationship between financial sector development and the growth process in Iran economy.

\section{The Theoretical Framework}

In this section, the nonlinear effects of different financial development indices on economic growth in Iran for the period 1973 to 2007 will be examined using seasonal data. It is worth noting that although, in Iran, several studies have examined the effects of financial sector development on economic growth; so far, no study has been done about the nonlinear effects of financial indices development on economic growth. Here, to explain the relationship between financial development and economic growth the framework offered by Odedokun (1996) is used which is based on the traditional aggregate production function of one-sector neoclassical economics given by:

$$
\mathrm{Y}_{\mathrm{t}}=\mathrm{f}\left(\mathrm{L}_{\mathrm{t}}, \mathrm{K}_{\mathrm{t}}, \mathrm{FD}_{\mathrm{t}}, \mathrm{Z}_{\mathrm{t}}\right)
$$

where $\mathrm{Y}$ is total production or real GDP, $\mathrm{L}$ is labor, $\mathrm{K}$ is capital stock, FD is financial development and $\mathrm{Z}$ is a vector related to the other factors which can be considered as an input of the production function. Also, $t$ represents time. Odedokun (1996) has emphasized the effects of financial intermediation development on economic growth. Following this study, papers related to the role of stock market in production growth increased strongly and demonstrated the significant positive relationship of stock market on economic growth empirically. In this regard, we can note the studies of Levine and Zervos (1998) and Arestis et al (2001). In addition, there are some studies that confirm the positive relationship between financial depth and economic growth such as Odhiambo (2007); Calderon and Liu (2003) and King and Levine (1993). In our article, we study and evaluate financial development in stock market, banking system and financial depth.

In the model of Odedokun (1996), $\mathrm{Z}$ is actual export, whereas, Bekaert et al (2001) and Zestos and Tao (2002) have pointed out that trade volume is significantly affecting economic growth. Inspired by these studies and according to Chang and Huang (2010), in this paper, the volume of real export and import has been also used as important and effective variables of economic growth. In addition, several studies have stated that government real expenditure 
has also important effects on economic growth, for example, we can point out De Gregorior and Guidotti (1995) and Barro (1997). Thus, in this model, real government expenditure is also included in the aggregate production function as a key factor. According to some studies such as Auty (1986, 1990, 1993, 1998 and 2001), Bulmer-Thomas (1994) and Gelb (1988), there exists a nexus between oil revenue and economic growth. Hence we add oil revenue as an important variable for Iran as the case of oil-exporting countries to the equation. Therefore, the model of Odedokun (1996) and Chang and Huang (2010) is modified as follows:

$$
Y_{t}=f\left(L_{t}, K_{t}, E X_{t}, I M_{t}, G C_{t}, B_{t}, S_{t}, O_{t}, D_{t}\right)
$$

Where $\mathrm{EX}_{\mathrm{t}}$ denotes real export; $\mathrm{IM}_{\mathrm{t}}$ denotes real import; $\mathrm{GC}_{\mathrm{t}}$ denotes real government expenditure; $\mathrm{B}_{\mathrm{t}}$ denotes banking development level; $\mathrm{S}_{\mathrm{t}}$ denotes stock market development level; $\mathrm{O}_{\mathrm{t}}$ denotes value of oil revenue and $\mathrm{D}_{\mathrm{t}}$ denotes financial depth level.

A popular generalization of ECM adds a threshold autoregressive (TAR) mechanism to

the standard ECM. The resulting model is referred to as the TAR-ECM specification. Let $\mathrm{X}=$ $\left(\mathrm{x}_{1}, \mathrm{x}_{2}, \ldots \mathrm{x}_{\mathrm{m}}\right)$ be the vector of variables and define different regimes based on threshold variable $\mathrm{q}_{\mathrm{t}}$ then, a two-regime TAR-ECM has the form:

$$
\begin{aligned}
\Delta \mathrm{x}_{1 \mathrm{t}} & =\left(\alpha \hat{\varepsilon}_{\mathrm{t}-1}+\sum_{\mathrm{i}=1}^{\mathrm{p}} \lambda_{\mathrm{i}} \Delta \mathrm{x}_{1 \mathrm{t}-\mathrm{i}}+\sum_{\mathrm{i}=0}^{\mathrm{p}} \gamma_{\mathrm{i}} \Delta \mathrm{x}_{2 \mathrm{t}-\mathrm{i}}+\ldots+\sum_{\mathrm{i}=0}^{\mathrm{p}} \delta_{\mathrm{i}} \Delta \mathrm{x}_{\mathrm{mt}-\mathrm{i}}\right) \mathrm{I}\left(\mathrm{q}_{\mathrm{t}} \leq \gamma\right)+ \\
& \left(\alpha \hat{\varepsilon}_{\mathrm{t}-1}+\sum_{\mathrm{i}=1}^{\mathrm{p}} \lambda^{*} \Delta \mathrm{x}_{1 \mathrm{t}-\mathrm{i}}+\sum_{\mathrm{i}=0}^{\mathrm{p}} \gamma_{\mathrm{i}}^{*} \Delta \mathrm{x}_{2 \mathrm{t}-\mathrm{i}}+\ldots+\sum_{\mathrm{i}=0}^{\mathrm{p}} \delta^{*} \Delta \mathrm{i}_{\mathrm{mt}-\mathrm{i}}\right) \mathrm{I}\left(\mathrm{q}_{\mathrm{t}}>\gamma\right)+\mathrm{e}_{\mathrm{to}}
\end{aligned}
$$

Where $\hat{\varepsilon}_{\mathrm{t}-1}$ is the estimated error correction term (the residual attained from long-run relationship). $\Delta \mathrm{x}_{1}$ is the dependent variable and $\Delta \mathrm{x}_{2} \ldots \Delta \mathrm{x}_{\mathrm{m}}$ and as well as their lags are independent variables in the error correction model. $\mathrm{P}$ is lag length, $\mathrm{q}_{\mathrm{t}}$ as noted above is the threshold variable and $\gamma(Y \in \Gamma)$ is threshold parameter. It should be noted that since the main series are non-stationary, the threshold variable is selected between first order difference of one of the exogenous variables or error correction term. The range denoted by $\Gamma$ is typically selected by sorting the observations on the threshold variable into an increasing order and by removing the bottom and top 15 per cent quantities. The resulting model is well identified for all possible thresholds. The error term e is assumed to be a Martingale difference sequence. The function of $\mathrm{I}\left(\mathrm{q}_{\mathrm{t}}>\gamma\right)$ is defined as follows:

$$
I_{t}= \begin{cases}0 & \text { if } q_{t} \leq \gamma \\ 1 & \text { if } q_{t}>\gamma\end{cases}
$$

The regression coefficients are: $\left(\alpha, \lambda_{i}, \gamma_{i}, \ldots, \delta_{i}\right)$ if $q_{t} \leq \gamma$ and $\left(\alpha^{*}{ }_{j} \lambda^{*}{ }_{i}, \gamma_{i}^{*}, \ldots, \delta_{i}^{*}\right)$ if $q_{t}>\gamma$. 


\section{Mll Macrothink}

Business and Economic Research

ISSN 2162-4860

2015, Vol. 5, No. 2

The coefficients of the first group correspond to the regime of lower values of $\mathrm{q}_{\mathrm{t}}$ and the coefficients of the second group correspond to the regime of upper values of $\mathrm{q}_{\mathrm{t}}$. In most cases, the threshold value $\gamma$ is unknown and should be estimated in addition to other parameters of the TAR model. Fortunately, Chan (1993) introduces a method to reach a consistent estimate of this threshold value. The procedure is as follows: for each possible value of the threshold (i.e. for each $\gamma \in \mathrm{r}$ ), a regression of the form (8) is estimated with least squares. For each regression, the sum of squared residuals $s(\gamma)$, is calculated. The threshold's estimate, $\hat{\gamma}$, is the argument that minimizes $s(\gamma)$. The last step of estimating the error correction model is testing the hypothesis of the linear model and the significance of the estimated threshold using bootstrapping and likelihood ratio test (Mehrara and et al, 2010).

\section{The Econometric Model}

According to the expressed theoretical framework and data accessibility, variables used in this study are as follows:

Table 1. Variable Definitions

\begin{tabular}{|c|c|}
\hline Variable & Description \\
\hline LGDP & Logarithm of gross domestic product to base price, fixed price in 1997 (billion rails) \\
\hline Llaborindex & $\begin{array}{l}\text { logarithm of labor index (this index is derived from the active population to total population } \\
\text { ratio }\end{array}$ \\
\hline Lcapstock & Logarithm of capital stock to fixed price in 1997 (billion Rials) \\
\hline Lexport & logarithm of export value to fixed price in 1997 (billion Rials) \\
\hline Limport: & logarithm of import value to fixed price in 1997 (billion Rials) \\
\hline Lgovexpen & Logarithm of government expenditure to fixed price in 1997 (billion Rials) \\
\hline Loilreve: & logarithm of oil revenue to fixed price in 1997 (billion Rials) \\
\hline Cointeg & component of long-term relationship disruption \\
\hline Lfinanceindex & logarithm of financial indices which following variables are used as these indices \\
\hline Ltashilindex & $\begin{array}{l}\text { logarithm of facility index (as one of financial indices), which is obtained from real remaining } \\
\text { of banking facilities to real GDP ratio. }\end{array}$ \\
\hline Lsahamindex & $\begin{array}{l}\text { logarithm of stock index (as one of financial indices) which is derived from stock exchange } \\
\text { value to fixed price to real GDP }\end{array}$ \\
\hline Lfinandepth & logarithm of liquidity to real GDP (financial depth) \\
\hline
\end{tabular}

Source of all data is the central bank.

Based on econometric tests, to specify the nonlinear model, these two steps must be taken:

1. specifying a linear error correction model to create a basic model for testing the null hypothesis of model linearity

2. estimating the threshold non-linear error correction model (TAR_ ECM) based on the apprised linear ECM

The threshold autoregressive error correction model (TAR_ECM) is made by generalization 


\section{Macrothink}

Business and Economic Research

ISSN 2162-4860

2015, Vol. 5, No. 2

of ECM equation and adding a threshold autoregressive (TAR) mechanism to the standard ECM. Therefore, according to theoretical framework of economic growth models and threshold models and to study the threshold effects of financial indicators growth such as stock index and banking facilities index on economic growth, economic growth model is specified as follows:

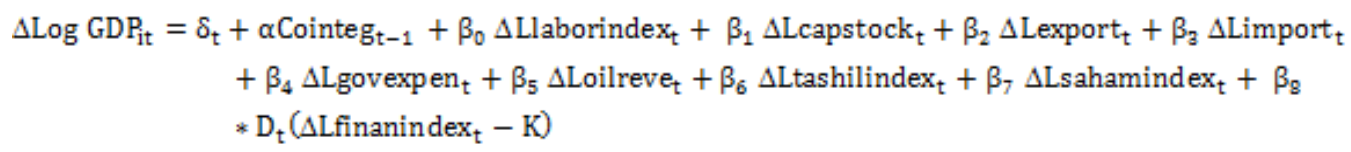

where Cointeg $\mathrm{t}_{\mathrm{t}-1}$ is the residual from long run relationship of GDP that it based on Eq.(11) according to:

$$
\text { Cointeg }_{t}=\mathrm{LGDP}_{t}-\gamma_{1} \text { Llaborindex }_{\mathrm{t}}-\gamma_{2} \text { Lcapstock }_{\mathrm{t}}-\gamma_{3} \text { Loilreve }_{\mathrm{t}} \text {-C }
$$

and $\Delta$ is a difference operator. $\mathrm{C}$ denotes intercept value, and $\mathrm{K}$ is the threshold parameter, also, $D_{\mathrm{t}}$ is a dummy variable, which is defined as follows:

$$
\mathrm{D}_{\mathrm{t}}= \begin{cases}0, & \Delta \mathrm{L} \text { finanindex } \\ 1, & \Delta \mathrm{L} \text { finaninde } \\ \mathrm{t} & >K\end{cases}
$$

In equation (10), instead of Lfinanindex the financial variable is placed to examine the non-linear relationship between each financial variable and economic growth. For example, if the purpose is to study the non-linear relationship between stock index and GDP growth, it is done by putting Lsahamindex instead of Lfinanindex in equation (10). Thus if the growth rate of stock index is lower than the estimated threshold, stock index growth will affect the economic growth with coefficient $\beta_{7}$. But by passing growth rate of stock index from a $\mathrm{K}$ threshold, this variable will impact on economic growth with coefficient $\beta_{7}+\beta_{8}$. The nonlinear relationship between other financial variables and economic growth are studied in the same manner.

In the error correction model (equation (10)), variables which contain a unit root can be considered in terms of first-order differential and stationary variables regarding level. The unit root test for the model variables is presented in the next section.

\section{Empirical Results}

In the GDP long-term relationship (equation (11)), with regard to theoretical bases of production functions and Iran economy's special conditions, a function of labor, capital, and 
oil revenue indices has been specified. First, we do unit root tests about the model's variables, and then we estimate the long-term relationship and identify the most important factors influencing the logarithm of GDP in the long run. Using the residuals of long-term relationship, we estimate the error correction model in both linear and non-linear (threshold) models.

\subsection{Static and Co-Integration Tests}

To analyze co-integration, the stationarity of the model variables was tested using Augmented Dickey-Fuller (ADF) and Phillips-Perron Unit root test. According to results of these two tests, all variables used in the model have a unit root and become stationary with a first order difference $^{3}$. Co-integration analysis has been used to study economic theories as well as to test the long-term equilibrium relationship among variables and its estimation. The main idea of co-integration analysis is that although many economic time series are non-stationary (contain random processes), in the long run, a linear combination of these variables may be stationary (and without random process).

One of the co-integration tests is the Engle-Granger test (1987) which is performed based on the stationarity test of regression residuals when variables of the co-integrated regression equation are unit root. The variables enter to the long-term model on the basis of the Cobb-Douglas production function. The key role of oil revenue in Iran's GNP was already discussed above (see also Mehrara and et al, 2010). The results of the co-integration relationship are shown in table (2).

Table 2. The results of long term relationship estimation

\begin{tabular}{|l|l|l|l|l|}
\hline Explanatory Variables & LLABORINDEX & LCAPSTOCK & LOILREVE & C \\
\hline \multirow{2}{*}{ Model 1 } & -0.28 & $1.07 *$ & $0.37 *$ & $-6.74^{*}$ \\
& $(0.29)$ & $(0.1)$ & $(0.02)$ & $(1.83)$ \\
\hline \multirow{2}{*}{ Model 2 } & --- & $0.82^{*}$ & $0.39 *$ & $-2.99^{*}$ \\
& & $(0.02)$ & $(0.01)$ & $(0.3)$ \\
\hline
\end{tabular}

* represents significance at 0.01 level Numbers in parentheses are standard errors of coefficients.

In model (1), unlike initial impression, the labor index (working population to total population ratio) has a negative effect on GDP. The coefficient of this variable is not statistically significant. Nevertheless, the negative sign may be generated by an increase in rent-seeking activities in Iran's economy, or by an increase in the number of unemployed people in working age. By removing the insignificant variable, the second model is statistically estimated. Residuals from the estimation of this relationship have I (0) integration, so there is a long-term relationship between three variables: GDP, capital and oil revenues ${ }^{4}$. Obtained disruption part series as error correction component are entered into the long-term error correction models.

\subsection{Short Run Coefficients Estimation and Analysis}

\footnotetext{
${ }^{3}$ - The results of the unit root tests are reported in the appendix.

4 - Multi-collinearity is tested by the variance inflation factor (VIF). All VIFs are less than 2 and according to the rule of thumb, the model didn't suffer from the problem of Multi-collinearity.
} 
In this section, using the error correction method (ECM) and threshold autoregressive error correction (ECM-TAR), we investigate the effect of these variables, especially financial variables, on economic growth in the short run.

\subsubsection{Linear Error Correction Model}

Considering theoretical literature about the impact of financial variables on economic growth as well as access to data, four different linear models have been specified and estimated using three financial variables. Each column of table (3) is devoted to the estimation of one setting. In the first model, the banking facilities index is used as the representative of financial sector. In the second and third models, stock index and financial depth, respectively, are used to represent the economy's financial sector. In the fourth model, the three financial variables have been entered into the model together.

Table 3. Results of short run relationship estimation

\begin{tabular}{|c|c|c|c|c|}
\hline Explanatory variables & I & II & III & IV \\
\hline C & $\begin{array}{c}0.00 \\
(0.00)\end{array}$ & $\begin{array}{c}0.00 \\
(0.00)\end{array}$ & $\begin{array}{l}0.01^{*} \\
(0.00)\end{array}$ & $\begin{array}{l}0.01^{*} \\
(0.00)\end{array}$ \\
\hline cointeg(-1) & $\begin{array}{l}-0.07^{*} \\
(0.02)\end{array}$ & $\begin{array}{c}-0.06^{* * *} \\
(0.04)\end{array}$ & $\begin{array}{c}-0.05^{* *} \\
(0.02)\end{array}$ & $\begin{array}{l}-0.04^{*} \\
(0.01)\end{array}$ \\
\hline$\Delta$ (Lcapstock) & $\begin{array}{l}0.75^{*} \\
(0.13) \\
\end{array}$ & $\begin{array}{l}0.32^{*} \\
(0.12) \\
\end{array}$ & $\begin{array}{c}0.5^{*} \\
(0.12) \\
\end{array}$ & $\begin{array}{l}0.47^{*} \\
(0.07) \\
\end{array}$ \\
\hline$\Delta($ Lexport $)$ & $\begin{array}{l}0.06^{* *} \\
(0.03)\end{array}$ & $\begin{array}{l}-0.05 \\
(0.03)\end{array}$ & $\begin{array}{c}0.02 \\
(0.02)\end{array}$ & $\begin{array}{l}-0.06^{* *} \\
(0.03)\end{array}$ \\
\hline$\Delta($ Limport $)$ & $\begin{array}{l}0.06^{*} \\
(0.01) \\
\end{array}$ & $\begin{array}{l}0.14^{*} \\
(0.02) \\
\end{array}$ & $\begin{array}{l}0.06^{*} \\
(0.01) \\
\end{array}$ & $\begin{array}{l}0.05^{*} \\
(0.01) \\
\end{array}$ \\
\hline$\Delta($ Lgovexpen $)$ & $\begin{array}{c}0.04 \\
(0.04)\end{array}$ & $\begin{array}{l}0.19^{*} \\
(0.05)\end{array}$ & $\begin{array}{c}0.03 \\
(0.03)\end{array}$ & $\begin{array}{l}0.14^{*} \\
(0.04)\end{array}$ \\
\hline$\Delta($ Llaborindex $)$ & $\begin{array}{l}1.35^{*} \\
(0.51) \\
\end{array}$ & $\begin{array}{l}1.18^{* * *} \\
(0.47)\end{array}$ & $\begin{array}{l}0.59^{* * *} \\
(0.32)\end{array}$ & $\begin{array}{l}1.12^{*} \\
(0.25)\end{array}$ \\
\hline$\Delta($ Loilreve $)$ & $\begin{array}{c}0.1^{*} \\
(0.03)\end{array}$ & $\begin{array}{l}0.17^{*} \\
(0.06)\end{array}$ & $\begin{array}{c}0.1^{*} \\
(0.02)\end{array}$ & $\begin{array}{l}0.21^{*} \\
(0.05)\end{array}$ \\
\hline$\Delta$ (Lfinandepth) & - & ........... & $\begin{array}{l}-0.3^{*} \\
(0.04) \\
\end{array}$ & $\begin{array}{l}-0.31^{*} \\
(0.04) \\
\end{array}$ \\
\hline$\Delta($ Ltashilindex $)$ & $\begin{array}{l}-0.02 \\
(0.03)\end{array}$ & ........... & ........... & $\begin{array}{l}-0.05^{* * *} \\
(0.02)\end{array}$ \\
\hline$\Delta($ Lsahamindex $)$ & …....... & $\begin{array}{l}-0.00^{* *} \\
(0.002)\end{array}$ & .......... & $\begin{array}{c}0.00^{*} \\
(0.001) \\
\end{array}$ \\
\hline$R^{2}$ & 0.92 & 0.93 & 0.94 & 0.83 \\
\hline
\end{tabular}

\footnotetext{
$*, * *$ and $* * *$ respectively indicate significance at $1 \%, 5 \%$ and $10 \%$ levels
}

Numbers in parentheses are standard errors of coefficients. 


\section{\لMacrothink}

Business and Economic Research

The results indicate that most of the estimated coefficients are statistically significant and have the expected signs. In all four models, the estimated error correction coefficients, -0.07 , $-0.06,-0.05$, and -0.04 respectively are significant and have the expected negative sign. This means that GDP deviation from its equilibrium value affects short run economic growth in a way that GDP returns to its equilibrium value. In all four estimated models, coefficients of capital growth, import growth, the labor index growth, and oil revenues growth are positive and significant. The positive effect of import growth on economic growth can be attributed to the entry of capital and intermediate goods, manufacturing raw materials which lead to higher production in the country. Export growth rate depending on the specified model has positive or negative effect on economic growth. However, this coefficient is not statistically significant in the second and third models.

Estimation obtained from the first model indicates that its financial variable, i.e. facility index, affects negatively economic growth. Nevertheless, this coefficient is not statistically significantly different from zero. In the second model in which stock index is used to represent the financial sector, carried out estimation shows that the growth of this variable has had a very small negative effect (close to zero) on Iran economic growth in the studied period. In model III, liquidity index to GDP (financial depth) is used as financial variable. The negative sign of the coefficient shows that the growth of this variable also reduces economic growth. This may be due to the detrimental effects of inflation on economic growth caused by liquidity which has an extensive literature. Finally, in the last model in which all three financial indicators have been used in one model, the results are largely consistent with those obtained in the first to third model and confirm them.

So growth of all three considered financial indicators, with negative coefficient, decreases economic growth. However, the growth of financial depth index may more severely reduce economic growth than other variables. The negative coefficient of banking facilities index can be found in several cases. Some reasons that can explain these negative effects include low interest rates of banking facilities which limit the reduction of production costs. This leads to modification of the production structure of some projects, improper allocation of credits by banks and also lack of using granted banking facilities in the productive projects and their entry into non-productive activities. The negative coefficients are in opposition to many studies emphasizing the positive effects of the financial market on economic growth. However, studies carried out in Iran show that the relationship between financial markets and Iranian economic growth is negative and minimal. In this regard, we can note Nyamongo and et al (2012); Rasti (1999); Samadi and et al (2007) and Rafiee (2003). Generally, the negative real interest rate in the context of Iran's emerging and unstructured financial market has prevented the financial markets (the banking sector and stock market) from playing their role in financial intermediation and contributing to economic growth. An increase in the inflation rate decreases the real return on all assets and therefore exacerbates the credit market frictions. These market frictions in turn lead to credit rationing, which intensifies the inflation. As a result, the financial sector grants fewer loans, resource allocation is associated with less efficiency, and the activities of financial intermediaries reduce because of respective negative consequences for investment. The decline in capital formation negatively affects the 


\section{Macrothink}

Business and Economic Research

ISSN 2162-4860

2015, Vol. 5, No. 2

long-term economic performance, the stock market and the bank sector activity (Huybens and Smith, 1999; Choi and Smith and Boyd, 1996). In order to verify our argumentation, we analyze the relevance of interest rate for the impact of financial development on economic growth subsequently. In 5-2-2 we show that the negative impact of the financial variables on growth predominantly can be observed in low interest regimes.

6.2.2 The Result of Nonlinear Models of Financial Index Effect According To Interest Rate Regimes

In this section, we specify and estimate another type of nonlinear model in relation to the effect of considered financial indices on economic growth. The purpose of specifying these models is to evaluate the direction and effect of each financial variable in high and low regimes of interest rates. It means whether the effect of financial indices growth on economic growth is different or not in various regimes of interest rate.

Table 4. Results of nonlinear short run relationship estimation based on interest rate as a threshold variable

\begin{tabular}{|c|c|c|}
\hline Explanatory variables & I & II \\
\hline C & $\begin{array}{c}0.00 \\
(0.00)\end{array}$ & $\begin{array}{c}0.00 \\
(0.00)\end{array}$ \\
\hline cointeg(-1) & $\begin{array}{l}-0.04^{* *} \\
(0.02)\end{array}$ & $\begin{array}{l}-0.07^{*} \\
(0.01)\end{array}$ \\
\hline$\Delta($ Llaborindex $)$ & $\begin{array}{l}1.57^{*} \\
(0.3)\end{array}$ & $\begin{array}{l}1.09^{*} \\
(0.24)\end{array}$ \\
\hline$\Delta($ Lcapstock $)$ & $\begin{array}{l}0.54^{*} \\
(0.08)\end{array}$ & $\begin{array}{l}0.53^{*} \\
(0.07)\end{array}$ \\
\hline$\Delta$ (Lexport) & $\begin{array}{l}-0.07^{* *} \\
(0.03)\end{array}$ & $\begin{array}{l}-0.01 \\
(0.03)\end{array}$ \\
\hline$\Delta$ (Limport) & $\begin{array}{c}0.02 \\
(0.01)\end{array}$ & $\begin{array}{c}0.1^{*} \\
(0.01)\end{array}$ \\
\hline$\Delta$ (Lgovexpen) & $\begin{array}{c}0.03 \\
(0.04)\end{array}$ & $\begin{array}{l}0.15^{*} \\
(0.04)\end{array}$ \\
\hline$\Delta$ (Loilreve) & $\begin{array}{l}0.29^{*} \\
(0.04)\end{array}$ & $\begin{array}{l}0.13^{*} \\
(0.03)\end{array}$ \\
\hline$\Delta($ Ltashilindex $)$ & ............ & $\begin{array}{l}-0.21^{*} \\
(0.04)\end{array}$ \\
\hline$\Delta($ Lsahamindex $)$ & $\begin{array}{c}0.00 \\
(0.00)\end{array}$ & ........... \\
\hline$\Delta($ Lsahamindex $) *(r>0.12)$ & $\begin{array}{l}0.02^{*} \\
(0.00)\end{array}$ & ........... \\
\hline$\Delta(\text { Ltashilindex })^{*}(r>0.12)$ & .......... & $\begin{array}{l}0.22^{*} \\
(0.04)\end{array}$ \\
\hline
\end{tabular}




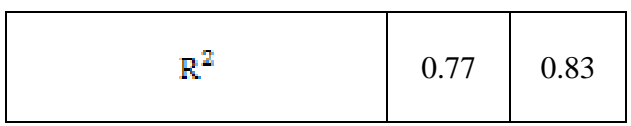

$*, * *$ and $* * *$ respectively indicate significance at $1 \%, 5 \%$ and $10 \%$ levels

Numbers in parentheses are standard errors of coefficients.

In both models, I and II, 12\% threshold interest rate is determined endogenously according to our explanations given in section 3. Based on the results of model I, stock index growth rate prior to threshold interest rate doesn't have a significant effect on GDP growth. Nevertheless, in high interest rate regime (higher than 12\%), stock index growth rate (stock trading value to fixed price to real GDP ratio) significantly affects economic growth with 0.02 positive coefficient. In model II which studies the non-linear effects of banking facilities index growth on economic growth, threshold interest rate is estimated $12 \%$ again. In the regime of low interest rate, banking facilities index growth rate reduces economic growth with a 0.21 negative and significant coefficient. However in high interest rate regime, the growth of this financial index doesn't reduce economic growth rate but increases economic growth with a $0.01(0.22-0.21)$ rate. As stated earlier, low interest rate (which is even lower than inflation) increases the demand for banking facilities and results in creating excess demand. In such circumstances, corruption and credit rationing will occur. Investment allocation becomes less efficient. Hence, economic growth is reduced. However, as a simple solution, the possibility of this outcome will be reduced by increasing interest rate.

6.2.3 The Result of Nonlinear Models Based On Stock and Banking Facilities as Threshold Variables

As stated earlier, the threshold autoregressive error correction model (TAR_ECM) is specified and estimated by generalizing the ECM equation and adding a threshold autoregressive (TAR) mechanism to the standard ECM. The estimated models have been reported in nonlinear form in table (5). Each of the models is assigned to the nonlinear effects of one financial variable on economic growth. To estimate these models we study the growth effects of these indices on economic growth in the two regimes of high and low financial index growth. In other words, in these models, we answer the question whether the effect of financial index growth on economic growth will be unique or change after crossing a threshold.

Table 5. Results of nonlinear short run relationships estimation based on stock and banking facilities indices as a threshold variable

\begin{tabular}{|c|c|c|}
\hline Explanatory variables & I & II \\
\hline C & 0.00 & 0.00 \\
& $(0.00)$ & $(0.00)$ \\
\hline cointeg(-1) & $-0.06^{*}$ & $-0.04^{* *}$ \\
& $(0.01)$ & $(0.01)$ \\
\hline \multirow{2}{*}{$\Delta$ (Llaborindex) } & $1.18^{*}$ & $1.44^{*}$ \\
& $(0.19)$ & $(0.29)$ \\
\hline
\end{tabular}




\begin{tabular}{|c|c|c|}
\hline$\Delta$ (Lcapstock) & $\begin{array}{l}0.43^{*} \\
(0.12) \\
\end{array}$ & $\begin{array}{c}0.5^{*} \\
(0.08) \\
\end{array}$ \\
\hline$\Delta$ (Lexport) & $\begin{array}{l}-0.02 \\
(0.04)\end{array}$ & $\begin{array}{c}-0.07^{*} \\
(0.03)\end{array}$ \\
\hline$\Delta$ (Limport) & $\begin{array}{c}0.1^{*} \\
(0.01)\end{array}$ & $\begin{array}{l}0.04^{*} \\
(0.01)\end{array}$ \\
\hline$\Delta($ Lgovexpen $)$ & $\begin{array}{l}0.12^{*} \\
(0.04)\end{array}$ & $\begin{array}{l}0.07^{* *} \\
(0.04)\end{array}$ \\
\hline$\Delta($ Loilreve $)$ & $\begin{array}{c}0.17^{*} \\
(0.04)\end{array}$ & $\begin{array}{l}0.33^{*} \\
(0.04)\end{array}$ \\
\hline$(\Delta$ (Ltashilindex $)$ & $\begin{array}{l}-0.01 \\
(0.03)\end{array}$ & ------- \\
\hline$(\Delta$ (Lsahamindex $)$ & ------- & $\begin{array}{c}-0.00^{*} \\
(0.04)\end{array}$ \\
\hline$\Delta($ Ltashilindex $) *(\Delta($ Ltashilindex $)>0.02)$ & $\begin{array}{l}-0.09 \\
(0.06)\end{array}$ & ................ \\
\hline$\Delta($ Lsahamindex $) *(\Delta($ Lsahamindex $)>0.1)$ & ------ & $\begin{array}{l}0.01^{*} \\
(0.00)\end{array}$ \\
\hline$R^{2}$ & 0.81 & 0.78 \\
\hline
\end{tabular}

$*, * *$ and $* * *$ respectively indicate significance at $1 \%, 5 \%$ and $10 \%$ levels

Numbers in parentheses are standard errors of coefficients.

In model I, banking facilities index growth rate is considered the threshold variable. Based on the estimated model and according to insignificance of the threshold variable (which is estimated $2 \%$ in this model), we can conclude that there isn't any nonlinear relationship between banking facilities index growth and economic growth. As essentially indicated in specifying the linear model and confirmed with this model (non-significance of $\Delta \dot{B}_{\mathrm{t}}$ ), there isn't any statistically significant relationship between banking facilities index growth and economic growth in Iran. Besides, once more in this model, the significant coefficient of error correction with the expected sign ensures the return of GDP level to its long-term equilibrium value after a deviation from equilibrium.

In model II, stock index which is obtained from stock trading value to fixed price to real GDP is considered the threshold variable. As can be observed, unlike banking facilities index, a nonlinear relationship between stock index growth and economic growth is approved. Estimated threshold level for growth of this index is $10 \%$. Below this threshold, the growth of this index has effect close to zero on economic growth. In contrast, if the growth rate of stock index exceeds $10 \%$, economic growth is increased with $0.01(0.00+0.01)$. So we can say that if the growth rate of the stock market index is $10 \%$ higher in Iran, it may detract somewhat from the effects of negative real interest rates and thus have a significant positive impact on economic growth. Other variables of this model, including error correction coefficient, are 
significant and interpretation is unchanged.

\section{Conclusion}

The financial sector is a large and growing part in both developed and developing economies in the world. Today, the development of different types of economic activities depends on their access to financial services. The idea of the effects of financial development on economic growth of a country is not a new thought and this relationship has been presented in many theoretical and empirical works. In recent years, also, many scientists tried to identify the variables that affect the strength and weakness of the relationship between the financial sector and economic growth. In this study, the importance of the interest rate for the relationship between the financial sector and the economic growth of Iran has been investigated. We applied the threshold autoregressive error correction method to data from 1973 to 2007. After studying the structural break and stationarity of variables by using error correction method (ECM), we examined the effect of financial variables on economic growth in the short run.

According to our data, the results of our models show that growth of all three financial indices reduces economic growth. However, the growth of financial depth index is the only financial index with significantly negative impact. The growth reducing impact of financial depth can mainly be explained through inflation effects. Because, in many years, the inflation rate is double digit and high in Iran. So inflation through negative real interest rate has significantly negative effect on performance of financial market in Iran's Economy (Salimifar and et al, 2012). Furthermore, the threshold autoregressive error correction model (TAR_ECM) is specified and estimated. In interest rate threshold models, results show that stock index's growth rate in low interest rate regime doesn't have a significant effect on economic growth but in high interest rate regime (over 12\%), growth rate of stock index significantly affects economic growth with a $2 \%$ positive coefficient. Banking facilities index growth reduces economic growth with a 0.21 negative and significant coefficient in low interest rate regime, but in high interest rate regime, the growth of this financial index increases economic growth with a 0.01 positive coefficient. With an interest rate lower than $12 \%$, real interest rate is negative or near zero, hence there is excess demand for banking facilities, resulting in credit rationing, an increase in corruption and a decrease in efficiency of capital allocation.

In the final section of the empirical results, each of models is assigned to the nonlinear effects of a financial variable on economic growth. With the first model, we show that there isn't any nonlinear relationship between banking facilities index growth and economic growth. In the second model, stock index is considered as threshold variable and a nonlinear relationship between stock index growth and economic growth is confirmed. Estimated threshold for the growth of this index is $10 \%$; such that before this threshold, the growth of this index has an effect close to zero on economic growth, but after passing the growth rate of this index from 10\%, stock index will increase economic growth. With regard to the lack of development in the stock market in comparison with the banking sector, the effect of stock market on economic growth is small (see Hasanzade and Ahmadian, 2010) or even negative. 
As already discussed with the model where the interest rate was the threshold variable, this is mainly due to negative real return induced by high inflation. Nevertheless, with stock market development and growth of this index over $10 \%$, the impact of stock market on economic growth is positive. In other words, when the stock index grows more than $10 \%$, the stock market will overcome the negative effects of inflation and increase economic growth.

\section{Appendix 1:}

The result of Augmented Dickey fuller test

\begin{tabular}{|l|l|l|}
\hline variable & level & First difference \\
\hline \multirow{2}{*}{ LGDP } & 0.01 & -3.34 \\
& $(0.95)$ & $(0.01)$ \\
\hline \multirow{2}{*}{ Llaborindex } & -0.84 & -1.69 \\
& $(0.35)$ & $(0.08)$ \\
\hline \multirow{2}{*}{ Lcapstock } & 0.18 & -2.85 \\
& $(0.97)$ & $(0.05)$ \\
\hline \multirow{2}{*}{ Lexport } & -2.54 & -3.7 \\
& $(0.11)$ & $(0.0)$ \\
\hline \multirow{2}{*}{ Limport } & -2.94 & -3.56 \\
& $(0.4)$ & $(0.00)$ \\
\hline \multirow{2}{*}{ Lgovexpen } & -2.62 & -3.79 \\
& $(0.1)$ & $(0.00)$ \\
\hline \multirow{2}{*}{ Loilreve } & -3.26 & -3.95 \\
& $(0.1)$ & $(0.00)$ \\
\hline \multirow{2}{*}{ Ltashilindex } & -1.79 & -3.03 \\
& $(0.38)$ & $(0.03)$ \\
\hline \multirow{2}{*}{ Lsahamindex } & -0.18 & -2.42 \\
& $(0.93)$ & $(0.01)$ \\
\hline \multirow{2}{*}{ Lfinandepth } & -0.51 & -3.04 \\
& $(0.88)$ & $(0.03)$ \\
\hline
\end{tabular}

Numbers in the parentheses are P- Values.

\section{References}

Ahmed, Abdullahi D. (2013). Effects of financial liberalization on financial market development and economic performance of the SSA region: An empirical assessment, Economic Modeling 30, 261-273. http://dx.doi.org/10.1016/j.econmod.2012.09.019

Apergis, Nicholas, FilippidisIoannis and Economidou, Claire (2007). Financial Deepening and Economic Growth Linkages: A panel Data Analysis, Review of World Economics, 143(1), 179-198. http://dx.doi.org/10.1007/s10290-007-0102-3

Arestis, P., Demetriades, P. O., Luintel, K. B. (2001). Financial development and economic growth: the role of stock markets. Journal of Money, Credit, and Banking, 33, 16-41. http://dx.doi.org/10.2307/2673870 
Barro, Robert J. (1990). Government spending in a simple model of economic growth. Journal of Political Economy, 98, 03-125. http://dx.doi.org/10.1086/261726

Barro, Robert J. (1997). Determinants of Economic Growth: A Cross-Country Empirical Study. The MIT Press, Cambridge.

Bekaert, G., Harvey, R., Lundblad, C. (2001). Emerging equity markets and economic development. Journal of Development Economics 66, 456-504. http://dx.doi.org/10.1016/S0304-3878(01)00171-7

Chan, K. S. (1993). Consistency and limiting distribution of the least squares estimation of a threshold autoregressive model. The Annuals of Statistics 21, 520-533. http://dx.doi.org/10.1214/aos/1176349040

Chang, Shu-Hwa. Huang, Liang-Chou. (2010). The nexus of finance and GDP growth in Japan: Do real interest rates matter?, Japan and the World Economy, 22, 235-24. http://dx.doi.org/10.1016/j.japwor.2010.06.004

Choi, S., Smith, B. D., \& Boyd, J. (1996). Inflation, Financial Markets, and Capital Formation, Federal Reserve Bank of St., Louis Review, 78, 9-35.

De Gregorior, J., Guidotti, P. (1995). Financial development and economic growth. World Development 23, 433-448. http://dx.doi.org/10.1016/0305-750X(94)00132-I

Demetriades, P. O., \& K. Hussein. (1996). Does Financial Development Cause Economic Growth?, Journal of Development Economics. http://dx.doi.org/10.1016/S0304-3878(96)00421-X

Dickey, D. A., \& Fuller, W. A. (1981). Distribution of the Estimators for Autoregressive Time Series with Unit Roots, Econometrica. http://dx.doi.org/10.2307/1912517

Engle, R. F., \& Granger, C. W. (1987). Co-integration and Error Correction: Representation, Estimation and Testing, Econometrica. http://dx.doi.org/10.2307/1913236

Fry, Maxwell J. (1982). Models of financially repressed developing economies, World Development, 10(9), Pages 731-750. http://dx.doi.org/10.1016/0305-750X(82)90026-2

Hasanzade, Ali. Ahmadian, Azam (2009). The effect of stock market development on economic growth, Journal of Money and Economy, 2, pp., 31-52.

Hicks, J. A. (1969), A Theory of Economic History, Oxford, Clarendon Press.

Huybens, E., \& Smith, B. D. (1999). inflation, Financial markets and long-run real activity, Journal of monetary Economics, 283-315. http://dx.doi.org/10.1016/S0304-3932(98)00060-9

Ireland, P. (1994). Money and Growth, American Economic Review.

Kumar Narayan, Paresh, Narayan, Seema. (2013). The short-run relationship between the financial system and economic growth: New evidence from regional panels, International Review of Financial Analysis, 29, 70-78. http://dx.doi.org/10.1016/j.irfa.2013.03.012 


\section{I Macrothink}

Business and Economic Research ISSN 2162-4860 2015, Vol. 5, No. 2

Levine, R. (1997). Financial Development and Economic Growth: Views and Agenda, Journal of Economic Literature, June, pp. 688-726.

Levine, R., Zervos, S. (1998). Stock market, banks, and economic growth, American Economic Review, 88, 537-558.

Levine, Ross, \& Zervos, Sara (1998). Stock Markets, Banks and Economic Growth, American Economic Review.

Levine, Ross, \& Zervos. (1969). Stock Markets, Banks, and Economic Growth, American Economic Review, June 1998, 88(3), 537-558.

Lucas, R. E. (1988). On the Mechanics of Economic Development, Journal of monetary Economics. http://dx.doi.org/10.1016/0304-3932(88)90168-7

Malho, E. Lazaros. (1986). Interest rate, savings and investment in developing countries, International Monetary Fund Staff Papers, 33(1), 90-116.

McKinnon, Ronald I. (1973). Money and Capital in Economic Development, Brookings Institution.

Mehrara, M., Maki, M., Tavakolina, H. (2010). The relationship between oil revenues and economic growth, using threshold methods (the case of Iran), OPEC Energy Review.

Naceur, s \& Samir Ghazouni. (2007). Stock markets, banks, and economic growth: Empirical evidence from the MENA region, Research in International Business and Finance, 21, 297-315. http://dx.doi.org/10.1016/j.ribaf.2006.05.002

Nyamongo, Esman Morekwa; Misati, Roseline N; Kipyegon, Leonard; Ndirangu, Lydia. (2012). Remittances, financial development and economic growth in Africa, Journal of Economics and Business, 64, 240-260. http://dx.doi.org/10.1016/j.jeconbus.2012.01.001

Odedokun, M. O. (1996). Alternative econometric approaches for analyzing the role of the financial sector in economic growth: time-series evidence from LDCs, Journal of Development Economics, 50, 119-146. http://dx.doi.org/10.1016/0304-3878(96)00006-5

Pagano, M. (1993). Financial Markets and Growth: An Overview, European Economic Review. http://dx.doi.org/10.1016/0014-2921(93)90051-B

Rafeei Karherodi, Reza. (2003). Financial intermediation and the economic growth in Iran, Master thesis, Esfahan University, Iran.

Rasti, Mohannad. (1999). The financial development and its effectiveness on the economic growth, Master thesis. Tehran University, Iran.

Rioja, F., Valev, N. (2004). Does one size fit all? A reexamination of the finance and growth relationship, Journal of Development Economics, 74, 429-447. http://dx.doi.org/10.1016/j.jdeveco.2003.06.006

Robinson, J. (1952). The Generalization of the General Theory, In The Rate of Interest and other Essays , London: Macmillan 


\section{Macrothink}

Business and Economic Research ISSN 2162-4860 2015, Vol. 5, No. 2

Romer, Paul M. (1986). Increasing returns and long-run growth, The Journal of Political Economy, 94, 1002-1037. http://dx.doi.org/10.1086/261420

Salimifar, M. Mojtahedi, S. Hadad Moghadam, M. Zendedel Shahrno, H. (2012). The investigation of effect of inflation on financial performance in Iran over the period 1973-2007, Journal of Studies in Applied Economics in Iran 2, 177-215.

Samadi, Saeed; Nasrollahi, Khadije, Karamalian Sichani, Morteza. (2007), The investigation between the financial market and the economic growth, Journal of Economic Research, 3, $2-15$.

Sassi, Seifallah. Goaied, Mohamed. (2013). Financial development, ICT diffusion and economic growth: Lessons from MENA region, Telecommunications Policy, 37, 252-261. http://dx.doi.org/10.1016/j.telpol.2012.12.004

Schumpeter, J. A. (1911). The Theory of Economic Development, Cambridge: Harvard University press.

Shaw, E. (1973), Financial Deepening in Economic Development, Oxford University Press

Van Wijnbergen, Sweder. (1983), Interest rate management in LDCs, Journal of Monetary Economics, 12(3), 433-452. http://dx.doi.org/10.1016/0304-3932(83)90063-6

Wachtel, P. (2001). Growth and finance: what do we know and how do we know it? International Finance, 43, 353-362. http://dx.doi.org/10.1111/1468-2362.00077

Zestos, G. K., Tao, X. (2002). Trade and GDP growth: causal relations in the United States and Canada, Southern Economic Journal, 68, 859-874. http://dx.doi.org/10.2307/1061496

\section{Copyright Disclaimer}

Copyright for this article is retained by the author(s), with first publication rights granted to the journal.

This is an open-access article distributed under the terms and conditions of the Creative Commons Attribution license (http://creativecommons.org/licenses/by/3.0/). 